Maša UZELAC

National University of Ireland Galway

Galway, Ireland

m.uzelac1@nuigalway.ie

\title{
URBAN SPACES, NON-PLACES AND BAD PLACES: INTERSECTIONS BETWEEN THEORY AND FICTION IN THE WRITINGS OF ALDOUS HUXLEY AND MICHEL HOUELLEBECQ
}

Recommended Citation: Uzelac, Maša. "Urban Spaces, Non-Places and Bad Places: Intersections Between Theory and Fiction in the Writings of Aldous Huxley and Michel Houellebecq". Metacritic Journal for Comparative Studies and Theory 6.1 (2020): https://doi.org/10.24193/mjcst.2020.9.08

\begin{abstract}
In exploring the nature of space in contemporary society, the writers Aldous Huxley and Michel Houellebecq adopt an anthropological approach which focuses on space as a product of human activities instead of an inorganic and stable entity. Their novels conceptualise their theoretical positionings on mobility in urban spaces, issues of identity, and influence of modern urban architecture on individuals and society. This paper demonstrates how in Huxley's and Houellebecq's writings urban environments reflect the individual and collective pathologies of the modern world. By referring to Lefebvre's theory of the social production of space and Augé's analysis of urban mobilities, this study explores the phenomena of consumption and commodification of urban spaces under capitalism. Following the postulates of the phenomenology of space, the paper also emphasises the negative experience of urban architecture, which shapes the individual's emotional response to both their physical and social environment.
\end{abstract}

Keywords: Huxley, Houellebecq, Lefebvre, space, architecture.

\section{Introduction}

The second half of the twentieth century brings a dramatic shift in the perception of the continuously changing world under developments of capitalism, the expansion of global 
markets and the advent of digital revolution. This period has also been marked by an increased interest in the issues of space and spatiality in critical theory. As a result of this, space is no longer examined as a geometrical, stable, and inorganic dimension, but as the outcome of human activities and underpinning of social relations. In the 1970s, Henri Lefebvre defined space as a product of forces of production and social relations of production, and thus put forward a theory of the production of space which brought together three concepts which used to be examined separately: economic, social and spatial (Lefebvre 210). Different forms of cultural production, however, manifested an interest in space even before this period. Lefebvre observes that avant-garde painters and modernist writers at the beginning of the century already heralded this socio-economicspatial triad by adopting new stylistic and formal strategies. With their fragmentary visual and writing techniques these artists depicted the emerging 'abstract' space that would finally become predominant after the shift from 'concrete' to 'abstract' labour in the system of production (Lefebvre 302-04)1. David Harvey contends that the change in artistic representations in early $2 \mathrm{O}^{\text {th }}$-century modernism "derived from a radical change in the experience of space and time in Western capitalism" (Harvey 29)². English author Aldous Huxley, with his 'counterpoint' technique based on juxtapositions of different writing styles, variety of (often contradictory) points of view, and complex spatial structures within the narrative, exhibits the nascent spatial tendency towards fragmentation. However, spatial issues were not only confined to stylistic and formal features. As a locus of major socio-economic changes, urban spaces have played a

${ }^{1}$ The increased division and specialisation of the forces of production eventually led to a divorce between labour and products of that labour. This abstraction of labour was made possible through the process of division of space itself - creation of 'abstract space' composed of disassociated specialised units in spaces of production, as well as modification of urban fabric divided by modern city planning practices into spaces of work, leisure and living (Lefebvre 266).

${ }^{2}$ According to Harvey, the source of modernity can be found in the eighteenth-century Enlightenment principle of rationality and belief in universal progress, whereas cultural modernism originated later, in post-1848 Western Europe. Harvey maintains that, by the early twentieth century, the thinking of Enlightenment was debunked as means of state domination based on bureaucratic rationality, along with the inequalities brought by the flourishing capitalist economic systems in the West. This new conception of the project of modernity provoked major transformations in various forms of modernist cultural production. The Enlightenment values of the eternal and universal were replaced by the ephemeral and fragmented. Techniques of montage/collage enabled writers and painters to render what Harvey names 'spatialization of time' - a shift in the perception of time and space provoked by the acceleration of production (the development of machines and factories), circulation (the advent of new systems of transportation and communication) and consumption (the expansion of advertising and mass markets) (Harvey 12-29). 
particularly important role in the analysis of an epoch marked by rapid development of industry, transportation, and commerce. In this sense, modernity - if understood as a socio-economic project inspired by the Enlightenment narrative of human progress - can be regarded as a prevailingly urban phenomenon (Harvey 25). The city has thus become and remained a big theme in literature throughout the $20^{\text {th }}$ century and beyond, until present times. Contemporary French writer Michel Houellebecq also demonstrates special interest in the problems of urban space. Social issues depicted in his novels stem directly from a variety of spatial aspects of the city3. The purpose of this article is to demonstrate to what extent Huxley and Houellebecq refer to issues of space and spatiality in order to depict the myriad of social pathologies in the modern world increasingly shaped by the forces of Western capitalist (soon to become global) economy. The two authors depict how modernity's project of progress evolved (through the development of mass production, mass market and advertising) from a primarily culturally and socially centred strategy to a politico-economically oriented one. The space of the modern city, acting as intermediary between the political-economic power and the social sphere reveals the major flaws of the dominant system. Both writers therefore observe modifications in natural and built environments, as well as changes in individual and social behaviour, as reflections of the current mode of production. The enhanced atomisation and individuation of society are seen as social manifestations of an economic system based on endless competition, division, and exclusion. In this context, space plays an important role in the analysis of both authors, as it allows the visualisation of these abstract concepts. The built urban environment is thus depicted as an instrument serving the interests of the dominant economic system, whereas the degradation of natural spaces reflects the devastating aspects of such systems.

This article focuses on Huxley's theoretical works on architecture and urbanism written in the 1920 s and published - some of them anonymously - in the magazines Vogue and House\&Garden, as well as some of his fiction writings from the inter-war

\footnotetext{
3 Moreover, Houellebecq's emphasis on the formal features of literary narratives which combine the most incongruous styles - from poetic, scientific, journalistic to pornographic writing, as well as a variety of language registers - from the most trivial to the sublime, is similar to the modernist experimentations with internal spatial arrangement, such as that of Huxley.
} 
period (Point Counter Point, Brave New World, and After Many a Summer)4. As a theoretical guide for analysis of Houellebecq's representations of urban spaces in the novels Whatever (Extension du domaine de la lutte), The Elementary Particles, The Map and the Territory and Serotonin, this article refers to the author's early essays "Approaches to Disarray" (1993) and H.P. Lovecraft - Contre le monde, contre la vie 5 (1991).

Urban areas are observed by both authors as theatres in which economic and social spheres are brought into most direct contact, thus shaping the new spatial forms (models of architectural, urbanistic and world-scale spatial planning), social practices taking place in that space (social behaviour), as well as people's personal response to the space around them (individual behaviour). In this regard, their analysis of space can be compared to that of Lefebvre, according to whom our overall understanding of space is composed of three levels of experience - 'conceived', 'perceived', and 'lived', and which the philosopher classifies within the theoretical categories of 'representations of space', 'spatial practice' and 'representational spaces' (Lefebvre 230, 246). Representations of space embody space conceptualised by specialists (scientists, politicians, urban planners, architects, etc.) and 'conceived' by its inhabitants. Spatial practice refers to the link between the daily routine of individuals and urban reality - that is, to the overall social practice in particular spaces (space as 'perceived'). 'Representational spaces' are spaces which are directly 'lived' through the creation of symbolic images which each individual associates with those spaces (Lefebvre 38-39).

This article examines Huxley's and Houellebecq's analyses of modern urban spaces and space-related issues through these three categories proposed by Lefebvre. A Lefebvrian reading of the two authors' fictional and theoretical writings on the topic contributes to the understanding of the relation between spatial, social, and economic aspects of the modern world. The two writers appear to share Lefebvre's conviction that capitalism, by dominating each of these aspects, exercises its control over the entire extent

\footnotetext{
4 Most of these theoretical works were published for the first time in the volumes six and nine of Aldous Huxley Annual: A Journal of Twentieth-Century Thought and Beyond in 2006 and 2009. James Sexton, who edited both volumes, explains that the overlapping of ideas from Huxley's inter-war period fictional writings and those from the essays suggests that he was the author of some of the anonymously written works (Sexton, "A New Huxley Miscellany" 5).

5 English translation by Dorna Khazeni published in 2005: H. P. Lovecraft: Against the World, Against Life.
} 
of human life. The present analysis offers an original approach to this discussion by combining two perspectives from different historical moments: Huxley's post-WWI vision of the gradual expansion of Western capitalist systems and Houellebecq's end-ofthe-century reaction to the accomplished global hegemony of neoliberal capitalism.

\section{Representations of Space: Urban Architecture}

The described changes in the politico-economic sphere naturally coincided with the changes in the practical arrangement of urban space or with what Lefebvre calls 'representations of space'. In the essay "Architecture and the Modern Environment", published in 1922, Huxley writes: "Art is not an isolated phenomenon (...). It springs out of life, and is immediately connected with it. The ideas and ideals, the material conditions of every age are reflected in its art, and in no art more than architecture" (Huxley, "Architecture and the Modern Environment" 26).

In this precise historical moment, around the early 1920s, numerous architects and architectural movements published manifestos and proclamations in favour of new forms of spatiality resulting from radical socio-economic transformations ${ }^{6}$. Harvey observes that, as machines and factories sprang up across Western cities after World War I, and new methods of transportation emerged, modernist architectural practices focused on the creation of more 'rationalised' urban spaces (Harvey 32).

Huxley, who worked as architectural critic at the time, extensively wrote on such developments which he saw as means of absolute domination of space by the capitalist regime. His essays and articles on architectural criticism largely inform the analysis of spatial settings and references in his fictional writings.

Houellebecq's general views on architecture are explained in detail in his essay "Approaches to Disarray" in which he characterises contemporary urban architecture by three aspects: it is functional, modest, and transparent. The writer's depictions of shopping malls, train stations, airports and other urban spaces in his novels perfectly reflect these three features. In this way Houellebecq shows how modern architectural practices exercise the dominant ideological discourse over the entire urban environment.

\footnotetext{
6 Bauhaus Proclamation from 1919, Le Corbusier's Ville Contemporaine (1922) and Mies van der Rohe's manifesto in G-Material zur elementaren Gestaltung (1923) (Frampton 123, 155, 162).
} 
The analysis of representational spaces in the following section will explore three aspects of space - function, structure and form - the unity of which corresponds to the overall 'use' of a particular work of architecture (Lefebvre 369).

\section{Functional features: 'machines-for-living-in'}

Huxley and Houellebecq both criticised the twentieth-century functionalist tendency in architecture. The English writer was particularly hostile towards Le Corbusier's projects of steel and concrete 'machines-for-living-in', which the architect proposed in the $1920 \mathrm{~s}$ and the early 1930s7. In the essay "Puritanism in Art" published in 1930 - undoubtedly referring already by its title to Le Corbusier's simplistic interior design style known as Purisme - Huxley writes: "Le Corbusier would compel us all to inhabit a mixture of greenhouse and hospital ward, furnished in the style of a dentist's operating chamber" (Huxley, "Puritanism in Art" 17). In "Notes on Decoration", published in the same year, Huxley refers to Le Corbusier's technique as "aseptic, hospital style of furnishing" and predicts the near future in which "the home will have all the appearance of a machine for living in" (Huxley, "Notes on Decoration" 14). As James Sexton notes, the dystopian urban arrangement of space in Huxley's famous novel Brave New World is to a great extent inspired by Le Corbusierian high-rise and high-density urban landscapes (Sexton, "Aldous Huxley on Architecture" 161). The architect's utilitarian logic, mirrored in his iconic phrase: "A city made for speed is a city made for success" (Frampton 155) is taken to extremes in Huxley's universe of gigantic buildings and high-speed helicopters.

Michel Houellebecq also appears to be very critical of Le Corbusier and particularly of his later influence on the French suburban housing projects from the $50 \mathrm{~s}$ and $60 \mathrm{~s}-$ also known as the grands ensembles (Houellebecq, "Approaches to Disarray"). In the novel The Map and the Territory the architect Jean-Pierre Martin characterises Le Corbusier's style as a "vision of a brutal, totalitarian mind (...) motivated by an intense taste for ugliness" (Houellebecq, The Map and the Territory). The oppressive Parisian landscapes of Houellebecq's novels feature a variety of Le Corbusier-inspired residential and office buildings. In Serotonin, the author describes the 31-storey tower Totem as "a

7 Charles Edouard Jeanneret, known as Le Corbusier (1887 - 1965) was a Swiss-born architect who later became a French citizen. Le Corbusier was one of the most important figures in the development of twentieth-century architecture, particularly the modernist movement (Frampton 149). 
gigantic concrete morel" (Houellebecq, Serotonin), perhaps echoing Huxley's references from Brave New World to "geometrical mushrooms" and "fungus [which] lifted towards the sky a disk of shining concrete" (Huxley, Brave New World).

In The Map and the Territory Houellebecq fiercely criticises Le Corbusier's positivistic aspirations for the machine-age society. To the "brutal and totalitarian" attitude of Le Corbusier, the fictional architect Jean-Pierre opposes a vision of "a complex, ramified, multiple architecture that [would leave] space for individual creativity", based on the ideas of Charles Fourier. Against "the taboo that Le Corbusier had placed on any form of ornamentation" the architect demands the right for everyone "to be surrounded by beautiful objects", as proclaimed by another utopian thinker, William Morris (Houellebecq, The Map and the Territory). In the essay "Sir Christopher Wren" Huxley praises the English architect who "desired that men and women should live with the dignity, even the grandeur, befitting their proud human title" (Huxley, "Sir Christopher Wren" 276). This conception of human dwelling certainly stands in sharp contrast to that of the Swiss-French architect's multipurpose structures of Ville Radieuse, designed to be, as Kenneth Frampton writes, "as ergonomically efficient as the sleeping cabins of a wagon-lit" (Frampton 179).

Huxley and Houellebecq show in this way how modernist architecture and urban planning practices, being based on the ideal of maximum economic utility, tend to reduce both spaces and people to their functional components in the system of production. Not only a house would be a 'machine for living in', as envisioned by Le Corbusier, but a man himself would become a 'man-machine'.

\section{Structural features: modesty}

Structural characteristics in architecture concern scale, proportion, dimension, and level (Lefebvre 158). Lefebvre claims that the abstract space of modernity is marked by the appearance, and gradual predominance, of the 'visual logic' in architecture. In The Production of Space, he writes:

An emphasis on visual space has accompanied the search for an impression of weightlessness in architecture. (...) Modernity expressly reduces so-called 'iconological' forms of expression (signs and symbols) to surface effects. Volumes or masses are deprived 
of any physical consistency. (...) interior walls (...) and interiors in general, are simultaneously losing all character or content. (Lefebvre 146-47)

The philosopher explains that such a tendency, with its pretention to a perfect 'readability' of space, has led to the abolishment of the 'impression of mass' in architecture. With the collapse of interior and exterior partitions, spaces become neutral, multifunctional and transparent (Lefebvre 147). Lefebvre's contention is that this apparent readability is designed to conceal the actual opacity of the space of capitalism in which the relations of power and forces of production - which in reality constitute it - remain hidden (Lefebvre 313).

In "Approaches to Disarray" Michel Houellebecq qualifies modern architecture as "a modest architecture" which "only displays (...) its presence as architecture by discreet allusions" - where effects of 'surface' have replaced those of 'volume' (Houellebecq, "Approaches to Disarray"). In order to depict the modesty of the works of architecture in his novels, Houellebecq uses language referring to the materials they are made of, their geometrical dimensions, or even just a concept of physical structure as an empty and abstract notion. Modernist blocks of flats in a Parisian residential area are thus "rectangular buildings with people living in them"; office buildings are "shells of buildings"; a seaside resort in Normandy is a complex of "concrete structures" (Houellebecq, Whatever); whereas one of the protagonists describes the place where he lives as "a kind of honeycombed structure of concrete and glass resting on four enormous raw concrete pillars" (Houellebecq, Serotonin) 8 .

Huxley also criticised the visual logic of the modern architectural practices of his time and, on several occasions, emphasised in his essays that depth, mass, and volume should be considered as the essential qualities of a work of architecture, which must always be perceived as a three-dimensional structure. In "Contemporary Architecture" the author writes that most of modern architecture lacks "harmonious proportion, dignity, the sense of scale" (Huxley, "Contemporary Architecture" 29). In the novel After Many a Summer Huxley depicts urban landscapes of Los Angeles which, as early as the 1930s, are already marked by the predominance of visual space. His allusion to "a ribbon

${ }^{8}$ Emphasis added. 
of concrete and suburban buildings" 9 which the protagonist Jeremy Pordage observes from the window of his car, implies the character's strictly visual, two-dimensional conception of the architectural space (Huxley, After Many a Summer 14). Describing the house of the head of the oiling company Jo Stoyte, the writer refers to it as a "spidery metal structure, carrying a succession of platforms" ${ }^{10}$ (Huxley, After Many a Summer 41). Space itself, reduced to its visual aspect, is in this way entirely negated. Baudrillard writes in this context in Simulacrum and Simulation that Los Angeles is "a city of incredible proportions but without space, without dimension" (Baudrillard 13). The 'destruction' of space through its visualisation is also evoked by Houellebecq in The Map and the Territory when the protagonist Jed Martin dreams of being "in the middle of a white, apparently limitless space" in which "no horizon could be made out, the mattewhite floor merging, very far away, with an identically colored sky" (Houellebecq, The Map and the Territory). The imaginary space of Jed's dream reflects the actual physical space deprived, through its absolute visualisation, of all content and character.

\section{Formal features: verticality and transparency}

The logic of visualisation brings a tendency in modern architecture towards vertical expansion and transparency. In the essay "The Problem of Architecture in the Town" published in 1922 Huxley notes that aesthetic change in favour of verticality is a direct expression of economic necessity and its underpinning political ideologies (Huxley, "The Problem of Architecture in the Town" 57, 60). Lefebvre also points out the symbolic meaning of verticality by aligning it with the "masculine' principle of power: "The arrogant verticality of skyscrapers, and especially of public and state buildings, introduces a phallic or (...) phallocratic element into the visual realm; the purpose of this display, of this need to impress, is to convey an impression of authority to each spectator" (Lefebvre 98).

Vertical expansion is the dominant spatial feature in Huxley's Brave New World where the roofs of enormous skyscrapers are "alive with the alighting and departure of helicopters"; where a building which has "only thirty-four stories"11 is considered small compared to its surroundings; and where a structure of "three hundred and twenty meters

\footnotetext{
9 Emphasis added.

${ }^{10}$ Emphasis added.

${ }^{11}$ Emphasis added.
} 
of white Carrara-surrogate" is described as "gigantically beautiful" (Huxley, Brave New World). Absolute power of the World State is reflected in the urban landscape, implying its violence and domination over the entire social space ${ }^{12}$. Lefebvre also notes that the logic of verticality leads to, although only in appearance, 'emancipation' of space from the land (Lefebvre 338). In this regard, Ronja Tripp rightly suggests that the urban vertical expansion of the World State is contrasted by the horizontality of the primitive Savage Reservation, thus suggesting the opposition between 'civilized' and 'barbaric' communities in the novel (Tripp 34). Verticality also concretises the hierarchy of relations in capitalist society. In Brave New World it is a reflection of the social status of the inhabitants of the World State. Physical height is therefore a quality exclusively reserved for the higher social classes of genetically engineered Alpha and Beta individuals. Huxley also draws attention to the principle of verticality in his novel After Many a Summer, as well as in the essay "Los Angeles. A Rhapsody", both describing the urban landscapes of Los Angeles from the early $20^{\text {th }}$ century. In the novel, Jeremy Pordage observes a succession of "tall buildings of a business district", whereas the essayist's gaze falls upon the buildings on which "the vertical lines of light went up like rockets into the dark sky. And [which] themselves - (...) had almost rocketed into existence"13 (Huxley, After Many a Summer 5; "Los Angeles. A Rhapsody” 226).

Houellebecq's references to the "gigantic concrete morel" of the 31-storey tower Totem (Houellebecq, Serotonin) or to the "appalling buildings" of the 33-storey Mercuriale towers (Houellebecq, The Map and the Territory) suggest the negative conception of the vertical logic reflected in modern architectural practices. It is perhaps for that reason, as an opposition to the 'masculine' principle of verticality, that the architect Jean-Pierre from the novel The Map and the Territory envisages an internal arrangement of space in which all vertical components would be replaced by excavations in the floor: "Thus, sleeping zones were rectangular excavations, forty centimetres deep; you descended into your bed rather than getting up into it. Similarly, the bathtubs were

${ }_{12}$ The main spatial setting in the novel is the technocratic World State governed by 'World controllers' and inhabited by artificially engineered citizens (tailored according to the State's economic needs). It is contrasted by the primitive Savage Reservation where humans still reproduce biologically and live freely. 13 Emphasis added. 
big round basins, the edges situated at floor level" (Houellebecq, The Map and the Territory).

Just as verticality is perceived by both authors as a direct expression of power and its violence, transparency - another aspect of visual logic - is also recognised as an echo of dominant ideology. Transparency appears as a more complex strategy which underlines a variety of meanings. Guy Debord observes that transparency allows perfect visibility of images which, detached from various aspects of life, are gathered in a 'spectacle'. As the philosopher writes, spectacle is "not a collection of images, but a social relationship between individuals, mediatised by images". Directly lived experience is thus completely transformed into 'representation' that is detached from reality (Debord 2-4). The messages or images which Debord refers to are those of advertising - 'positive images' evoking the concepts of happiness, well-being, and beauty. Lefebvre explains that this 'world of signs' and images presents itself as reassuring in its opposition to the 'real' world. By exercising fascination, fraudulent signs finally seduce the spectator and divert his attention from the real (Lefebvre 389).

For Houellebecq, the role of transparency is precisely to ensure the 'maximum readability' of space "destined to be crossed by an uninterrupted succession of textual, visual, and iconic messages" (Houellebecq, “Approaches to Disarray"). The author's descriptions of the train station Lyon Part-Dieu in the novel Whatever perfectly demonstrate how in transparent spaces images tend to replace space itself:

Above the bus station proper rises a hypermodern structure in glass and steel, with four or five levels linked by stainless steel escalators which are activated at the least approach; (...) luxury shops (...) with absurdly aggressive window displays; (...) All around there are monitors which broadcast pop promos and adverts. (Houellebecq, Whatever)

Likewise, in Huxley's Brave New World the simulated environment completely takes over the natural one. Nature is referred to as something menacing and appalling compared to the comforting world of images. The two inhabitants of the World State, Lenina and Henry, are thus reassured by the fact that "the electric signs shut off the outer darkness" so that they "still retained their happy ignorance of the night" (Huxley, Brave New World). The public space of Huxley's Los Angles in the novel After Many a Summer is 
entirely constructed of the commercial landscape which Jeremy observes from his car as a succession of visual messages and signs:

ASTROLOGY, NUMEROLOGY, PSYCHIC READINGS.

DRIVE IN FOR NUTBERGERS (...).

CASH LOANS IN FIFTEEN MINUTES (...).

CLASSY EATS. MILE HIGH CONES.

JESUS SAVES.

HAMBURGERS (Huxley, After Many a Summer 6-8)

What Baudrillard wrote about another American city, Las Vegas, in Simulacra and Simulation, can also be applied here: "advertising is not what brightens or decorates the walls, it is what effaces the walls, effaces the streets, the facades, and all the architecture" (Baudrillard 92).

According to Baudrillard, an overabundance of images in the absolutely transparent space ends up replacing the 'reality' of that space. Space becomes 'simulacra' in which the real is substituted by the images of the real - the 'hyperreal' (Baudrillard 2). Huxley and Houellebecq depict how in modern urban environments advertising images excessively invade public spaces and transform them into abstract spaces in which individuals no longer recognise themselves. Alienated from their environment, individuals themselves turn into 'abstractions'. The protagonist from Houellebecq's novel Whatever thus compares the movements of the cleaning operatives in his office to an "impression of life unfolding in slow motion"14 (Houellebecq, Whatever). Similarly, Huxley in the essay "Los Angeles. A Rhapsody" refers to the actors on a Hollywood film set as "corpse-lights" (Huxley, "Los Angeles. A Rhapsody" 223). The modelled space of a film setting extends to the whole urban fabric of the city of Los Angeles, overwhelmed by advertising, as Huxley later described in the novel After Many a Summer.

14 Emphasis added. 


\section{Spatial Practice: Urban Mobility and Issues of Identity}

One of the most prominent effects of the domination of space by capitalism is the increased mobility of urban spaces. The social purpose of a city - that of providing the possibility of meeting through its particular arrangement of space (Norberg-Schulz 55) is abolished in favour of the possibility of movement, stemming from an economic purpose: the unobstructed circulation of commodities, capital and people. Lefebvre notes in this context that traditional urban activities disappear as the movement becomes a mere "gestural simulation of formerly urban activity of encounter" (Lefebvre 313).

Huxley and Houellebecq depict how the social dynamics of modern urban space change with its enhanced economic activities. The French author writes in "Approaches to Disarray" that all contemporary urban architecture therefore "must be considered to be one immense system for accelerating and rationalizing human movements" whose ideal realisation would be that of "the system of highway interchanges" (Houellebecq, "Approaches to Disarray"). His fictional characters, while seeking a brief solace in the change of place, are particularly annoyed with any obstacle or hindrance to their movement - railway strikes, malfunctioning electronic timetables at bus and train stations, loss of car, even speed limits on highways. As Florent-Claude from Houellebecq's novel Serotonin observes, movement offers a brief glimmer of hope "turned towards a possible future" (Houellebecq, Serotonin).

For Huxley, who lived through the rapid development of means of transportation in the first half of the $20^{\text {th }}$ century, the appearance of the private automobile is an event of special importance. "I can talk for hours about motors with other car-owners", writes Huxley about his personal obsession with cars in the essay "Wander Birds" (Huxley, "Wander Birds" 16). Despite his own predilection, the author in the same essay also admits the dangers of such a tendency, characterising it as a "disease [which] spreads with every fresh expansion of Henry Ford's factories" (Huxley, "Wander Birds" 24). With the development of means of transportation, as remarked by Lefebvre, many urban spaces are transformed by the practices of urban planning into intersections of roads. In this way, as the philosopher writes, "city life is subtly but profoundly changed, sacrificed to that abstract space where cars circulate like so many atomic particles" (Lefebvre 312). This emerging space of mobility is thoroughly described in Huxley's novels where certain episodes unfold as the protagonists drive in their cars through urban environments. It is 
through one such scene that the reader gets the best picture of the character Everard Webley from the novel Point Counter Point. His physical movement through London occasionally interrupted by different obstacles on the road such as the unloading of a railway delivery van, provoking a feeling of discomfort for the character - is followed by the unravelling of Everard's stream of consciousness. In the midst of the complex network of urban intersections, Everard drives in full speed, but as soon as he enters a park the rhythm of his thoughts becomes more serene and he slows down the vehicle. The chaotic rhythm of urban traffic is transposed by Huxley onto the mental space of the character, whose thoughts rush through his mind in uncoordinated flows, mirroring the movements of "the towering buses roar[ing] before him" (Huxley, Point Counter Point). Similarly, in Huxley's essay on Los Angeles, as the car in movement changes its position, the perspective of the writer-observer also changes, and each chapter of the essay thus gives information on a different aspect of city life. Hence the musical metaphor in the title and a particular arrangement of chapters which are accordingly named "First Movement", "Second Movement" etc. (Huxley, "Los Angeles. A Rhapsody"). This narrative technique resembles the one Huxley used in the opening scene of his novel After Many a Summer, where the protagonist discovers different aspects of the city of Los Angeles as "Southern California roll[s] past the windows" of his car. From the "slum of Africans and Filipinos, Japanese and Mexicans” Jeremy's gaze is suddenly confronted by a drastically different urban reality as "the car plunge[s] into a tunnel and emerge[s] into another world, a vast, untidy, suburban world of filling-stations and billboards, of low houses and gardens, of vacant lots and waste-paper, of occasional shops and office buildings and churches" (Huxley, After Many a Summer 4-5).

For writer Philip Quarles from the novel Point Counter Point movement is also a sort of liberating force. Quarles observes that 'taking roots' in a particular place means losing personal freedom: "I have a terror of losing my freedom. Free, without ties, unpossessed by any possessions, free to do as one will, to go at a moment's notice wherever the fancy may suggest-it is good" (Huxley, Point Counter Point). Whereas Huxley's characters manage to take some pleasure in their mobility, Houellebecq's protagonists, as Katherine Gantz notes, "never [stay] in place long enough to transform mere observation into experience" (Gantz 157). A "possible future" is never reached and the consolation they have been looking for is never found in the activity of movement. The 
protagonist from Whatever, while aimlessly wandering through a residential area in the suburbs of Rouen, thus realises that nothing justified his presence there - "neither [ $t$ ]here nor anywhere else", as he immediately concludes (Houellebecq, Whatever).

Sociologist John Urry observes that enhanced movement in the space controlled by capitalism problematises the relationship between the social and the spatial (Urry 164). The general understanding is that we gain our identity from a particular place invested with meaning and common practices shared by a certain community. Place "makes life visible", as Norberg-Schultz suggests (Norberg-Schulz 51). Anthropologist Marc Augé observes that places in urban areas, under the impact of the dominant mode of production, tend to become what he calls 'non-places'. Non-places represent installations and means "needed for the accelerated circulation of passengers and goods" (Augé 34). Augé explains the difference between non-places and 'anthropological' places as follows: “'Anthropological place' is formed by individual identities, through complicities of language, local references, the unformulated rules of living know-how; non-place creates the shared identity of passengers, customers or Sunday drivers" (Augé 101).

Houellebecq depicts most contemporary urban areas as dehumanising spaces which hinder social interactions and foster individualism. Indeed, individuals in his novels rarely interact, and if they do, it is most often as fellow passengers or consumers. And, while for Augé non-places par excellence are related to means of transport, airports, train stations and supermarkets, Houellebecq extends this notion to all urban spaces. The protagonist from his novel Platform, while waiting for his flight at Phuket airport in Thailand, observes that "more and more, the whole world would come to resemble an airport" (Houellebecq, Platform). This perfectly conceptualises Augé's idea that "the possibility of non-place is never absent from any place" (Augé 107). Social relations in the fully mobilised urban environment are reduced to short-lived interactions between commuters on the train, drivers on the road, customers and service providers in supermarkets, shopping malls etc. As Urry suggests, individual identity in late-stage capitalism is in this way replaced by the "market identity of a consumer" (Urry 21). In this regard, Katherine Gantz characterises the houellebecquian protagonist as a "postmodern flâneur" - urban wanderer whose casual strolling in the city necessarily ends, not in 
encounter, but in consumption (Gantz 153) ${ }^{15}$. She specifically refers to the episode of Bruno's "nutritious trip down the boulevard Saint-Michel" in the novel The Elementary Particles in which the protagonist's movement through the city is occasionally interrupted by the consumption of food and pornography (Houellebecq, The Elementary Particles).

Huxley observes that individual identity in modern society has been replaced by a role that the subject has in the current mode of production. Describing the businessman Jo Stoyte in the novel After Many a Summer Huxley writes that Stoyte's social status was measured by his reputation, and that the man was simply an "embodiment of [his] function" (Huxley, After Many a Summer 138). This implies that for the English writer, whose literary career roughly coincides with the last stages of the Western industrial society, the identity of a 'producer' is still the most prominent characteristic of an individual.

In the post-industrial society of Houellebecq, however, identities become even more fluid and interchangeable, as they are constantly renewed through the process of consumption. Spierings and van Houtum suggest that in what they call 'post-society', the consumer is engaged in the constant search for an 'up-to-date identity' (Spierings and van Houtum 903). In "Approaches to Disarray" Houellebecq observes that the ephemeral and contingent attachment to space in consumerist cultures provokes a "proliferation (...) of violent identity reflexes". Under the influence of advertising and its endless reproduction of desire, the individual is transformed into an "obedient ghost of becoming" (Houellebecq, "Approaches to Disarray"). Huxley also predicts such a tendency in Brave New World in which the society of the World State follows the principle known as "ending is better than mending", which implies the constant creation of new forms of consumption, and therefore identities (Huxley, Brave New World). In both cases (that of Huxley's industrial society in Brave New World and Houellebecq's post-industrial society), individual identities dissolve into their social (i.e. economic) function - either that of producer or that of consumer. World State's motto in Brave New World "COMMUNITY, IDENTITY, STABILITY", represents precisely the absolute opposite of

\footnotetext{
${ }_{15}$ Similarly, Delphine Grass observes that Houellebecq's commuter is no longer capable of establishing correspondences like Baudelaire's flâneur, since the city itself is transformed into "a vector of transition" where movement "abolishes the notion of space itself" (Grass 345-46).
} 
its actual values where the spirit of community is replaced by individualism, identity is deconstructed into economic purpose and stability is disrupted by the constant change renewal of commodity offers, desires and identities (Huxley, Brave New World).

Both Huxley and Houellebecq depict urban areas increasingly invaded by spaces of transition and consumption. The English author describes in his novels how the mobilisation of urban fabric contributes to the shaping of new forms of personal and cultural identity. Houellebecq ironically observes in The Map and the Territory that in the total absence of traditional public spaces, places of consumption like Casino supermarket and Shell service stations become the "only perceptible centres of energy, the only social propositions" 16 (Houellebecq, The Map and the Territory). This way, the function of the city is completely reversed: instead of fostering social interactions, contemporary urban spaces "generate loneliness", as one of Houellebecq's characters observes (Houellebecq, Serotonin).

\section{Representational Spaces: the Phenomenology of Urban Space}

Aldous Huxley and Michel Houellebecq often emphasise the importance of the affective response to space or what Lefebvre named representational space. This understanding is close to Bachelard's concept of a phenomenology of space which privileges the imaginative (mental activity) over the physical (activity of senses) experience of space (Bachelard 23). In the essay "Rimini and Alberti" Huxley writes that, in works of architecture, "the worship of form should come to be connected in so many cases with the worship of a moral ideal", which explains why "art is so often religious" (Huxley, "Rimini and Alberti" 272). Similarly, in the essay about the architect Christopher Wren, the author writes that the quality of Wren's style is "a quality rather moral than aesthetic" (Huxley, "Sir Christopher Wren" 276). In "The Problem of Architecture in the Town" he emphasises that "the sense of solidity and the feeling of depth are in the very nature of the emotion which one derives from a fine piece of architecture"17 (Huxley, "The Problem of Architecture in the Town" 57). Huxley in this way attempts to draw attention to the inner

16 Emphasis added.

${ }_{17}$ Emphasis added. 
experience caused by space, which appears as much more complex than the one stemming from visual observation.

Likewise, for Houellebecq, works of architecture often refer to the realm beyond physical perception. In this regard it is important to examine the passages from his early novel Whatever, in which the writer depicts how hostile urban spaces impact the individual's relationship with himself, with others, and with the world. Here, Houellebecq uses spatial metaphors in order to describe the psychological disorders of the depressed protagonist. The unnamed character observes that "his skin has become a frontier", or that he feels as if "things are falling apart within him, like so many glass partitions shattering", and also that "the world around [him] appear[ed] high"18 (Houellebecq, Whatever). Michael G. Kelly rightly observes that these descriptions suggest the "overlapping of both rationality and affect with physical perception" (Kelly 74), thus bringing together the conceived, the perceived and the lived. In his critical work on Lovecraft - H. P. Lovecraft. Contre le monde, contre la vie - Houellebecq examines representations of architecture by the American writer. Lovecraft's poetic descriptions of space escape, as Houellebecq suggests, any "attempt of [their] visual adaptation"19, since those are the images appearing in one's individual consciousness - images which are 'dreamt of', instead of seen. Such a representation of space has the power to immerse the reader "into a real ecstatic delirium" 20 because it is "based on a living and emotional conception of the world" ${ }^{21}$ (Houellebecq, H. P. Lovecraft. Contre Le Monde, Contre La Vie). This suggests that for Houellebecq, as for Huxley, the imaginative dimension of the overall experience takes precedence over the physical.

This understanding is the same as Bachelard's, for whom the 'imagined values' of space complement and finally dominate the 'material' ones. In his Poetics of Space Bachelard explains that the space seized by imagination is the one which is 'lived', and not merely observed (Bachelard 17). The inability of individuals to experience space on the level of imagination - to associate it with symbolic images - suggests that such space is in itself 'unliveable'. In Huxley's and Houellebecq's novels even the most intimate spaces,

\footnotetext{
18 Emphasis added.

19 "La lecture de ces descriptions (...) décourage ensuite toute tentative d'adaptation visuelle" (My translation).

20 "plonge dans un véritable délire extatique" (My translation).

21 "repose sur une conception vivante et émotionnelle du monde" (My translation). Emphasis added.
} 
such as private homes, are perceived merely as crossing points between spaces of work and consumption. The very concept of dwelling fundamentally changes, as a place of living takes on the character of spaces of transition. Huxley's protagonist in After Many a Summer describes the house of the oil company owner Jo Stoyte as an empty and neutral space: "The Object impended, insolently enormous. Nobody had dealt poetically with that" (Huxley, After Many a Summer 23). The writer's allusion to the lack of poetical imagination and his emphasis on the material characteristics of space - by using the word 'object' with the capital $\mathrm{O}$, and by adding emphasis on 'that' - suggest that the space of Stoyte's house does not generate any emotional response and therefore remains in the realm of 'conceived' and 'perceived', instead of 'lived'. In Houellebecq's Whatever the unnamed protagonist describes the apartment of his colleague Jean-Yves in an impersonal tone devoid of any affective value: "He was living in a studio flat in the $15^{\text {th }}$ arrondissement. The heating was included in the rent. He barely did more than sleep there, since he was in fact working a lot" (Houellebecq, Whatever). Agathe NovakLechevalier rightly suggests that Houellebecq's novels depict an "inaptitude to construct what was once called 'dwelling', impossibility to feel 'at home' in a world that seems more and more foreign, more and more indifferent, incapability to live in some place"22 (NovakLechevalier 111-12).

By insisting on the lack of any phenomenological sense of space in modern urban surroundings, Huxley and Houellebecq emphasise how the process of individuation of society is linked to the abstraction and dehumanisation of its physical environment. The hostile character of urban public spaces extends to the private ones: home no longer offers a refuge from the outside world, but becomes another 'non-place' within the global space dominated by capitalism.

\section{Conclusion}

Huxley's and Houellebecq's negative evaluation of modern practices of urban planning and architecture, expressed both in their critical and fiction writings, articulates the two authors' complex critique of capitalist society. Dominating economic forces are observed

\footnotetext{
22 "Inaptitude à construire ce que l'on appelait autrefois un « foyer », impossibilité de se sentir « chez soi » dans un monde qui paraît de plus en plus étranger, de plus en plus indifférent, incapacité, donc, à habiter quelque part: (...).” (My translation)t.
} 
through the impact they have on individual and social behaviour, as well as on the physical environment. This way, both authors demonstrate that economic, social, and spatial orders are intrinsically intertwined. Space is observed as an extension of living bodies and the relations between these bodies, whose behaviour is on the other hand constrained by the current mode of production. In this regard, the spatial theory of Henri Lefebvre, which describes space as a network of interrelations between forces of production and social relations of production, informed this analysis to the greatest extent (see Lefebvre 210).

Huxley and Houellebecq show that the space of modernity under the hegemony of capitalism is the space in which different domains are connected and interrelated: economic and social, social and individual, local and global. The urban spaces depicted in their novels, with a focus on conceived, perceived and lived experience, give a great account of the development and expansion of capitalism and its effects on both individual subjects and society. The city in Huxley's and Houellebecq's writings is thus far from an empty space in which individuals simply entertain their relations and perform their practices - it is the very underpinning of those relations and practices. Hostile modern and contemporary architecture and arrangements of space are not simply perceived as visually displeasing aspects of the city, but as oppressive forces which shape the relationships between individuals and the individual's relationship with themselves. The two authors' writings perfectly demonstrate how urban spaces reflect the much wider set of social and economic issues in the modern world.

\section{References:}

Augé, Marc. Non-Places: An Introduction to Supermodernity. Verso, 2009.

Bachelard, Gaston. La Poétique de l'espace. Quadrige, 1992.

Baudrillard, Jean. Simulacra and Simulation. Edited by Sheila Glaser, The University of Michigan Press, 1994.

Debord, Guy. La Société Du Spectacle. Gallimard, 1996.

Frampton, Kenneth. Modern Architecture. A Critical Theory. Thames and Hudson, 1996.

Gantz, Katherine. "Strolling with Houellebecq: The Textual Terrain of Postmodern Flanerie." Journal of Modern Literature, vol. 28, no. 3, 2005, pp. 149-61, doi:https://doi.org/10.1353/jml.2005.0037. 
METACRITIC JOURNAL FOR COMPARATIVE STUDIES AND THEORY 6.1

Grass, Delphine. "The Disappearing Subject: Language, Transparency, and Modern Architecture in the Works of Michel Houellebecq." Contemporary French and Francophone Studies, vol. 15, no. 3, 2011, pp. 339-47, doi:10.1080/17409292.2011.577619.

Harvey, David. The Condition of Postmodernity: An Enquiry into the Origins of Cultural Change. Blackwell Publishers, 1992.

Houellebecq, Michel. "Approaches to Disarray." Purple Diary, 2016, https://purple.fr/magazine/fw-2016-issue-26/michel-houellebecq-exhibition-atthe-palais-de-tokyo-paris/.

---. H. P. Lovecraft. Contre Le Monde, Contre La Vie. Kindle ed., Editions du Rocher, 1999.

---. Platform. Edited by Mytriam Frendo and Frank Wynne, Kindle ed., Random House Trade Paperbacks, 2011.

---. Serotonin. Edited by Shaun Whiteside, Kindle ed., Farrar, Straus and Giroux, 2019.

---. The Elementary Particles. Edited by Frank Wynne, Kindle ed., Alfred A. Knopf, 2000.

---. The Map and the Territory. Edited by Gavin Bowd, Kindle ed., Alfred A. Knopf, 2012.

---. Whatever. Edited by Paul Hammond, Kindle ed., Serpent's Tail, 2011.

Huxley, Aldous. After Many a Summer. Chatto and Windus, 1939.

---. "Architecture and the Modern Environment." Aldous Huxley Annual: A Journal of Twentieth-Century Thought and Beyond, vol. 6, 2006, pp. 26-28.

---. Brave New World. Kindle ed., RosettaBooks, 2010.

---. "Contemporary Architecture." Aldous Huxley Annual: A Journal of TwentiethCentury Thought and Beyond, vol. 6, 2006, pp. 29-31.

---. “Los Angeles. A Rhapsody.” Aldous Huxley’s Stories, Essays, \& Poems, J. M. Dent \& Sons, 1954, pp. 223-29.

---. "Notes on Decoration." Aldous Huxley Annual: A Journal of Twentieth-Century Thought and Beyond, vol. 3, 2003, pp. 11-14.

---. Point Counter Point. Penguin Books, 1975.

---. "Puritanism in Art." Aldous Huxley Annual: A Journal of Twentieth-Century Thought and Beyond, vol. 3, 2003, pp. 15-17.

---. "Rimini and Alberti." On Art and Artists - Literature, Painting, Architecture, Music, edited by Morris Philipson, Meridian Book, 1960, pp. 266-72. 
---. "Sir Christopher Wren." On Art and Artists - Literature, Painting, Architecture, Music, edited by Morris Philipson, Meridian Book, 1960, pp. 272-78.

---. "The Problem of Architecture in the Town." Aldous Huxley Annual: A Journal of Twentieth-Century Thought and Beyond, vol. 9, 2009, pp. 57-60.

---. "Wander Birds." Along the Road. Notes and Essays of a Tourist, Chatto and Windus, 1948, pp. 15-24.

Kelly, Michael G. "Literary Individuation and the Ethnography of Indifference: Reading Augé after Houellebecq." Irish Journal of French Studies, vol. 9, 2009, pp. 69-92.

Lefebvre, Henri. The Production of Space. Edited by Donald Nicholson-Smith, Blackwell Publishing, 2008.

Norberg-Schulz, Christian. The Concept of Dwelling. On the Way to Figurative Architecture. Rizzoli Electa, 1985.

Novak-Lechevalier, Agathe. "Comment Habiter Le Monde? Michel Houellebecq Architecte.” Modern \& Contemporary France, vol. 27, no. 1, 2019, pp. 111-28, doi:10.1080/09639489.2018.1558193.

Sexton, James. "A New Huxley Miscellany." Aldous Huxley Annual: A Journal of Twentieth-Century Thought and Beyond, vol. 9, 2009, pp. 1-12.

---. "Aldous Huxley on Architecture." Aldous Huxley Annual: A Journal of TwentiethCentury Thought and Beyond, vol. 16, 2016, pp. 143-72.

Spierings, Bas, and Henk van Houtum. "The Brave New World of the Post-Society: The Mass Production of the Individual Consumer and the Emergence of Template Cities." European Planning Studies, vol. 16, no. 7, 2008, pp. 899-909, doi:10.1080/09654310802224702.

Tripp, Ronja. "Biopolitical Dystopia: Aldous Huxley, Brave New World (1932)." Dystopia, Science Fiction, Post-Apocalypse: Classics - New Tendencies - Model Interpretations, edited by Eckart Voigts and Alessandra Boller, Wissenschaftlicher Verlag Trier, 2015, pp. 29-45.

Urry, John. Consuming Places. Routledge, 1995. 